\title{
A Study of Screening Tests for the Presumptive Diagnosis of Significant Bacteriuria in Urinary Tract Infections
}

\author{
Pradnya Naik* and Maria Jose Pinto \\ Department of Microbiology, Goa Medical College, Bambolim, Goa 403202, India \\ *Corresponding author
}

\begin{tabular}{|l|}
\hline K e y w o r d s \\
$\begin{array}{l}\text { Urinary tract } \\
\text { infection, Screening } \\
\text { tests, Leucocyte } \\
\text { esterase test }\end{array}$ \\
\hline Article Info \\
\hline $\begin{array}{l}\text { Accepted: } \\
\text { 04 August } 2019 \\
\text { Available Online: } \\
\text { 10 September } 2019\end{array}$ \\
\hline
\end{tabular}

\section{A B S T R A C T}

Urinary tract infections (UTIs) are the inflammatory disorders of the urinary tract caused by the abnormal growth of pathogens. Microscopy of urine is of diagnostic value and culture is still the gold standard for isolation of bacteria. However presumptive approach with non -culture rapid screening tests is more practical and cost-effective to manage UTI. The present study is therefore being undertaken to evaluate the usefulness of several laboratory based rapid screening tests compared to culture. The study was undertaken in the Department of Microbiology, Goa Medical College on 200 urine samples that were collected randomly from patients, attending the Out Patient Department. Urine samples were collected from patients with a provisional diagnosis of urinary tract infections, based on clinical history alone of patients who have not received any antibiotic treatment. Each sample was processed as follows: i) Semi quantitative culture ii) Non culture screening tests: a)Wet mount examination b) Gram staining c) Griess nitrite test d) Triphenyl Tetrazolium Chloride test e) Catalase test f) Leucocyte Esterase dipstick test. Out of 200 samples processed by semi-quantitative loop method, significant bacteriuria was observed in $62 \%$ cases. The sensitivity of LE dipstick test was highest (92.7\%), followed by Griess Nitrite test $(88.7 \%)$ and wet mount for pyuria $(87.9 \%)$. However, the difference in sensitivity of the various tests was not significant. The negative predictive value was highest with the Leucocyte esterase test (88.5\%) and least with catalase test $(69.2 \%)$. The negative predictive value was the least with catalase test. The values were calculated with respect to culture. Rapid detection of significant bacteriuria can have profound effect on patient care as well as laboratory economics. This is because it avoids unnecessary antibiotic therapy to patients with normal urine. Secondly, it prevents the cost of labor and material by helping to avoid culturing of negative urine specimens. Hence, the need for rapid and more accurate methods for detection of significant bacteriuria is very important.

\section{Introduction}

Urinary tract infections (UTIs) are the inflammatory disorders of the urinary tract caused by the abnormal growth of pathogens. ${ }^{1}$
Urinary tract infection (UTI) is an acute bacterial infection of the urinary tract, which is accounting for around 8 million patient visits annually. ${ }^{2}$ Urinary tract infections can be community acquired or nosocomial. ${ }^{3,4}$ 
Complications of UTI include pyelonephritis requiring hospitalization and can result in permanent renal damage. UTI is most commonly caused by uropathogens from faecal flora that ascend the urethra to infect the bladder. ${ }^{5}$ Young women who are sexually active are particularly vulnerable. In pregnancy, bacteriuria can lead to complications such as pyelonephritis, sepsis, and increased risk of preterm birth. ${ }^{6}$

All individuals are susceptible to UTI, but the prevalence depends on age, gender and certain predisposing factors. The infections may range from asymptomatic infection to simple acute symptomatic infection with a susceptible organism to a more serious recurring infection such as pyelonephritis which may be caused by resistant and often difficult to treat organisms. ${ }^{7}$

From a microbiological perspective, UTI exists when pathogenic microorganisms are detected in the urine. Thus Microscopy of urine is of diagnostic value and culture is still the gold standard for isolation of bacteria. It is now universally accepted that cultural isolation of the particular causative agent is important for a definite diagnosis of urinary tract infection. However presumptive approach with non-culture rapid screening tests is more practical and cost-effective to manage UTI. A positive result for bacteriuria provides enough evidence of infection to omit urine culture and susceptibility testing and treat the patients empirically with presumptive approach. The various screening methods would reliably and economically separate specimens, which contain evidence of clinical infection from those which do not. Thus, this can help to avoid culture of all irrelevant specimens.

Rapid detection of significant bacteriuria can have profound effect on patient care as well as laboratory economics. This is because it avoids unnecessary antibiotic therapy to patients with normal urine. Secondly, it prevents the cost of labor and material by helping to avoid culturing of negative urine specimens. Hence, the need for rapid and more accurate methods for detection of significant bacteriuria is very important. Several biochemical urine screening methods have been described such as assays for leucocyte esterase activity, nitrate reduction and glucose detection. Physical methods, such as impedance, filtration, particle counting and microscopic examination have also been reported, in addition to semiautomatic systems. ${ }^{8}$

The present study aims at establishing the usefulness of several laboratory based rapid screening tests, such as gram staining, determination of pyuria and bacteriuria by wet mount examination and biochemical tests like leucocyte esterase. Finally relevant information drawn from this study was compared with those of other workers, both within and outside our country.

\section{Materials and Methods}

The present study was undertaken in the Department of Microbiology, Goa Medical College, Bambolim Goa, over a period of 5 months, from January to May, 2019. The material for the study included two hundred samples that were collected randomly from patients, attending the Out Patient Department of this Institution.

\section{Selection of subjects}

Urine samples were collected from patients with a provisional diagnosis of urinary tract infection, based on clinical history alone. Only those patients who had not received any antimicrobial treatment were included in the study. 


\section{Collection of sample}

Subjects were instructed to collect an early mid stream clean catch urine in a sterile container. The males were instructed to first clean genitals with soap and water and then collect urine after retracting prepuce and the glans penis. The women were asked to collect urine after careful anogenital toilet with soap and water. The female patients were instructed to separate the labia with fingers, while collecting the urine. The samples were refrigerated when a delay of more than 1-2 hours was anticipated in transportation of the samples.

\section{Processing of samples}

Each sample was processed as follows:

i) Semi quantitative culture and antimicrobial sensitivity testing

ii) Non culture screening tests

a) Wet Mount examination

b) Gram staining

c) Griess nitrite test

d) Triphenyl Tetrazolium Chloride test

e) Catalase test

f) Leucocyte Esterase dipstick test

\section{Semi quantitative culture ${ }^{9}$}

Semi quantitative culture was performed by using a calibrated platinum loop with a diameter of $1.45 \mathrm{~mm}$ calibrated to deliver $0.001 \mathrm{ml}$ of urine by a streak plate method. A loopful of uncentrifuged urine was inoculated on blood agar and MacConkey agar. It was streaked on MacConkey agar plate employing an inverted cone technique. ${ }^{10}$ The streaking on blood agar plate employed was using primary, secondary and tertiary streak. After overnight incubation at $37^{\circ} \mathrm{C}$, colony count was done and significant bacteriuria was reported at a count of $\geq 10^{5} \mathrm{CFU} / \mathrm{ml}$.

\section{Wet mount examination}

A wet mount examination was done for detection of both pyuria and bacteriuria after centrifugation. ${ }^{11}$ Approximately $12 \mathrm{ml}$ of urine was centrifuged in a tube at 2500 to 3000 rpm for 5 minutes.

The supernatant was discarded and a drop of the deposit was put on a slide. The drop was covered by a coverslip and observed under a high power objective. ${ }^{11}$ The number of organisms per high power field was examined (least 10 organisms/HPF) for bacteriuria, and the number of pus cells per $20 \mathrm{HPF}$ were counted (more than 10 pus cells/ $20 \mathrm{HPF}$ ) for pyuria.

\section{Gram stain $^{11}$}

A smear was prepared on a slide, heat fixed and stained by Gram staining technique. The sediment obtained by centrifuging urine. The slide was then observed under oil immersion objective for presence of bacteria. Presence of $\geq 1$ organism/OIF was considered positive. At least 50 fields were examined before declaring the smear negative.

\section{Griess nitrite test ${ }^{12}$}

Preparation of Reagents: Solution A Sulphanilic acid solution and Solution B alpha - Naphthylamine solution. Sulphanilic acid solution was prepared by dissolving 0.5 gm of sulphanilic acid in $150 \mathrm{ml}$ of $10 \%$ acetic acid. $\alpha$ - Naphthylamine solution was prepared by dissolving $0.2 \mathrm{gm}$ of $\alpha$ - Naphthylamine in $20 \mathrm{ml}$ of distilled water which was heated to boiling.

After thorough stirring, the solution was filtered through filter paper. Equal amounts of solution A and solution B were mixed to obtain a working reagent. The combined reagent if pink in colour was unfit for use. 


\section{Method of urine testing for nitrites}

A few $\mathrm{ml}$ of the urine was placed in a testtube. To the urine sample, one-fourth to onehalf volume of the combined reagent solution was added. In the presence of nitrite, a red colour developed instantaneously and remained stable for several hours. This was taken as a positive test result.

Triphenyl tetrazolium chloride test (TTC) ${ }^{13}$

\section{Preparation of the reagent}

Stock solution was prepared by dissolving 750 $\mathrm{mg}$ of TIC in $100 \mathrm{ml}$ of a saturated solution of disodium hydrogen phosphate. The stock solution was stored in the dark and was stable for at least two months. Working Solution was prepared by taking $4 \mathrm{ml}$ of the stock solution and diluting it to $100 \mathrm{ml}$ with saturated solution of disodium hydrogen phosphate. The working solution was also stored in the dark and was stable for at least two weeks.

\section{Test procedure}

Two $\mathrm{ml}$ of well mixed urine was taken in a clean test-tube and $0.5 \mathrm{ml}$ of the working solution of TIC was added to it with a sterile pipette. The tube was then incubated for four hours at $37^{\circ} \mathrm{C}$. At the end of four hours, the deposit was examined with the naked eye. A positive result was shown by a red precipitate of triphenyl formazan while a negative result by the absence of this precipitate. A concave mirror was used to read the result.

\section{Catalase test $^{14}$}

The catalase test was performed by mixing equal volumes of urine and freshly prepared $3 \%$ hydrogen peroxide (weight in volume) in a sterile test tube. The tube was left standing in a rack at room temperature and the presence of a definite layer of foam on the surface of the mixture at the end of 15 minutes was regarded as a positive reaction to the catalase test.

\section{The leucocyte esterase dipstick test ${ }^{15}$}

The Leucocyte Esterase dipstick test was performed using the Multistix $® 10$ SG Reagent strips, manufactured by Bayer Diagnostics Manufacturing Ltd, South Wales. These strips contained solid phase reagent areas affixed to a plastic support and provided in a dry reagent format.

\section{Procedure}

The test was performed on well mixed uncentrifuged urine, according to the manufacturer's instructions. The strip was completely immersed in the urine and removed immediately to avoid dissolving out reagents. While removing, the edge of the entire length of the strip was run against the rim of the urine container to remove excess urine. The strip was held in a horizontal position to prevent possible mixing of chemicals from adjacent reagent areas. The test results were carefully compared with the colour chart on the bottle label in good day light. Time reading was 60 seconds for nitrites and 2 minutes for leucocytes. The positivity of the LE dipstick test was decided when either leucocyte esterase was positive, or nitrite was positive or both leucocyte esterase and nitrites were positive.

\section{Statistical analysis}

The sensitivity, specificity and positive and negative predictive values were calculated by using the following formulae. ${ }^{16}$

a) Sensitivity =

Number of the positive results $\times 100$ No. of true positive + No. of false negatives 
Specificity $=$

Number of the negative results $x 100$

No. of true negative + No. of false positives Positive predictive value $=$

Number of true positive results $x 100$

No. of true positive + No. of false positive results

Negative predictive value $=$

Number of true negative results $x 100$

No. of true negative + No. of false negative results

A) True positive $=$ culture positive + test positive

B) False negative $=$ culture positive + test negative

C) True negative $=$ culture negative + test negative

D) False positive $=$ culture negative + test positive

Culture negative $=$ samples with no growth, samples with non- significant bacteriuria and those with polymicrobial growth.

\section{Results and Discussion}

The prospective study included a bacteriological analysis of 200 clean catch early morning midstream, randomly selected urine samples from patients with clinical suspicion of urinary tract infection. The study was carried out over a period of 5 months from January to May 2015.

Table No. 1 depicts the culture result of the study samples by semi-quantitative loop method. Out of 200 samples processed, significant bacteriuria was observed in 124 cases i.e. $62 \%$. While doubtful bacteriuria with bacterial counts between $10^{4}$ and $10^{5}$ org $/ \mathrm{ml}$ was encountered in 3 cases ie. $1.5 \%$. Growth of contaminants was seen in $20.5 \%$ cases (41/200) while sterile cultures were obtained in $16 \%$ cases. Among the significant bacteriuria cases, single pathogen was obtained in $91.9 \%$ cases (114 out of 124 cases), while two organisms were grown in 10 patients urines $(8.1 \%)$.

Wet mount examination of urine for pus cells and bacteria was suggestive of urinary tract infection in $61 \%$ and $56 \%$ of cases respectively, while gram staining of centrifuged deposit of urine indicated UTI in $57 \%$ of cases.

The above Table No. 3 indicates that the Griess nitrite test was positive in $60 \%$ of cases, while the TTC test and catalase tests were positive in $29.5 \%$ and $28 \%$ cases respectively.

The Leucocyte esterase dip stick test is indicative of the presence of nitrites and leucocyte esterase activity showed a positive test result of a $60 \%$ for nitrites and $61 \%$ for leucocyte esterase.

Pyuria: sensitivity $=87.9 \%$ specificity $=82.9 \%$

Bacteriuria: sensitivity $=82.3 \%$ specificity $=86.8 \%$

Gram staining: sensitivity $=85.5 \%$ specificity $=89.5 \%$

Wet mount examination and gram staining is compared with culture result in Table 5. The wet mount preparation for pus cells gave a true positive result in 109 cases (87.9\%), false negative result in 15 cases $(12.1 \%)$, false positive result in 13 cases $(17.1 \%)$ and true negative result in $82.9 \%$ cases $(n=63)$. Thus the sensitivity and specificity of this test was $87.9 \%$ and $82.9 \%$ respectively.

The wet mount preparation for bacteria gave a true positive result in $82.3 \%$ cases, false negative result in $17.7 \%$ cases, false positive result in $13.2 \%$ cases and true negative result in $86.8 \%$ cases. Thus the sensitivity was $82.3 \%$ and the specificity was $86.8 \%$. 
Gram staining showed a true positive result in $85.5 \%$ cases, false negative result in $14.5 \%$ cases and false positive and true negative results in $10.5 \%$ and $89.5 \%$ cases respectively. The sensitivity and specificity was $85.5 \%$ and $89.5 \%$ respectively.

From the above two charts, it is evident that the sensitivity and specificity of the Griess Nitrite test, when compared with culture result was $88.7 \%$ and $86.8 \%$ respectively. The test gave a true positive result in 110 cases $(88.7 \%)$ and a false positive result in $13.2 \%$ cases. A false negative result was seen in 14 cases $(11.3 \%)$ while a true negative result was seen in $86.8 \%$ cases.

The sensitivity and specificity of the TTC test, when compared with culture test (Table 7) was $79.8 \%$ and $78.9 \%$ respectively. A true positive result was seen in $79.8 \%$ cases while a false negative result was obtained in 25 cases (20.2\%). A false positive and true negative result was seen in $21.1 \%$ and $78.9 \%$ cases respectively.

The catalase test when compared with culture (Table no.8) showed a sensitivity of $80.6 \%$ and specificity of $71.1 \%$. False negative result was seen in $19.4 \%$ cases, while false positive was observed in $28.9 \%$ cases. The leucocyte esterase dip-stick test gave a true positive result in 115 cases out 124 culture positive cases, the sensitivity being $92.7 \%$. The specificity was $90.8 \%$. False positive result was obtained in $9.2 \%$ cases, while false negative result was seen in $7.3 \%$ cases.

From the above Table No.10, it is evident that the sensitivity of LE dipstick test was highest (92.7\%), followed by Griess Nitrite test $(88.7 \%)$ and wet mount for pyuria $(87.1 \%)$. The negative predictive value was highest with the Leucocyte esterase test i.e. $88.5 \%$ and least with catalase test $(69.2 \%)$. Table no. 10 depicts the results of different tests employed in the study, in terms of sensitivity, specificity, negative and positive predictive values. The values were calculated with respect to culture. The sensitivity of LE dipstick test was highest, followed by nitrite test and wet mount for pyuria. However, the difference in sensitivity of the various tests was not significant. The negative predictive value was the least with catalase test.

\section{Interpretation of results}

\begin{tabular}{|l|c|c|}
\hline Culture result & No. of samples & Percentage \\
\hline $\begin{array}{l}\text { Significant } \\
\text { bacteriuria }\end{array}$ & 124 & 62 \\
\hline $\begin{array}{l}\text { Doubtful } \\
\text { Bacteriuria }\end{array}$ & 3 & 01.5 \\
\hline $\begin{array}{l}\text { Growth } \\
\text { contaminants }\end{array}$ & 41 & 20.5 \\
\hline No growth & 32 & 16 \\
\hline Total & 200 & 100 \\
\hline
\end{tabular}

N.B. Figures in parenthesis indicate percentage 
Table.2 Results of wet mount examination and Gram staining $(n=200)$

\begin{tabular}{|l|c|c|}
\hline Test result & No. positive & No. negative \\
\hline Wet Mount Pus cells & $122(61)$ & $78(39)$ \\
\hline Wet Mount bacteria & $112(56)$ & $88(44)$ \\
\hline Gram Staining & $114(57)$ & $86(43)$ \\
\hline
\end{tabular}

N.B. Figures in parenthesis indicate percentage

Table.3 Results of Griess nitrite, TTC and catalase test

\begin{tabular}{|l|c|c|c|}
\hline Test & Total No. tested & No. Positive & Percentage \\
\hline Griess nitrite test & 200 & 120 & 60.0 \\
\hline TTC test & 200 & 115 & 57.5 \\
\hline Catalase test & 200 & 122 & 61.0 \\
\hline
\end{tabular}

Table.4 Results of leucocyte esterase dipstick test

\begin{tabular}{|l|c|c|}
\hline Test & No. of Positives & Percentage \\
\hline Nitrite & 120 & 60 \\
\hline Leucocyte esterase & 122 & 61 \\
\hline
\end{tabular}

Table.5 Comparison of wet mount examination and gram staining with culture method

\begin{tabular}{|c|c|c|c|c|}
\hline $\begin{array}{l}\text { Wet } \\
\text { Mount/Gram } \\
\text { stain }\end{array}$ & & $\begin{array}{c}\text { Significant } \\
\text { bacteriuria } \\
n=124\end{array}$ & $\begin{array}{c}\text { Doubtful } \\
\text { bacteriuria / } \\
\text { growth of } \\
\text { contaminants } \\
n=44\end{array}$ & $\begin{array}{c}\text { No } \\
\text { growth } \\
\mathbf{n}=32\end{array}$ \\
\hline \multirow[t]{2}{*}{ Pus cells } & $\begin{array}{l}\text { Positive } \\
(\mathrm{n}=122)\end{array}$ & $\begin{array}{c}109 \\
(87.9)\end{array}$ & $\begin{array}{c}10 \\
(22.7)\end{array}$ & $\begin{array}{c}3 \\
(9.4)\end{array}$ \\
\hline & $\begin{array}{c}\text { Negative } \\
(\mathrm{n}=78)\end{array}$ & $\begin{array}{c}15 \\
(12.1)\end{array}$ & $\begin{array}{c}34 \\
(77.3)\end{array}$ & $\begin{array}{c}29 \\
(90.6)\end{array}$ \\
\hline \multirow[t]{2}{*}{ Bacteria } & $\begin{array}{l}\text { Positive } \\
(n=112)\end{array}$ & $\begin{array}{c}102 \\
(82.3)\end{array}$ & $\begin{array}{c}7 \\
(15.9)\end{array}$ & $\begin{array}{c}3 \\
(9.4)\end{array}$ \\
\hline & $\begin{array}{c}\text { Negative } \\
(\mathrm{n}=88)\end{array}$ & $\begin{array}{c}22 \\
(17.7)\end{array}$ & $\begin{array}{c}37 \\
(84.1)\end{array}$ & $\begin{array}{c}29 \\
(90.6)\end{array}$ \\
\hline \multirow[t]{2}{*}{$\begin{array}{l}\text { Gram } \\
\text { Staining }\end{array}$} & $\begin{array}{l}\text { Positive } \\
(n=114)\end{array}$ & $\begin{array}{c}106 \\
(85.5)\end{array}$ & $\begin{array}{c}6 \\
(13.6)\end{array}$ & $\begin{array}{c}2 \\
(6.2)\end{array}$ \\
\hline & $\begin{array}{c}\text { Negative } \\
(n=86)\end{array}$ & $\begin{array}{c}18 \\
(14.5)\end{array}$ & $\begin{array}{c}38 \\
(86.4)\end{array}$ & $\begin{array}{c}30 \\
(93.8)\end{array}$ \\
\hline
\end{tabular}

N.B. Figures in parenthesis indicate percentage 
Table.6 Comparison of the Griess nitrite test with culture method

A)

\begin{tabular}{|c|c|c|c|c|c|}
\hline Culture results & $\begin{array}{c}\text { Total } \\
\text { no. of } \\
\text { samples }\end{array}$ & $\begin{array}{c}\text { True } \\
\text { positive } \\
\text { (out of } \\
\text { 124) }\end{array}$ & $\begin{array}{c}\text { False } \\
\text { negative } \\
\text { (out of } \\
\text { 124) }\end{array}$ & $\begin{array}{c}\text { False } \\
\text { positive } \\
\text { (out of } \\
76)\end{array}$ & $\begin{array}{c}\text { True } \\
\text { negative } \\
\text { (out of } 76 \text { ) }\end{array}$ \\
\hline Significant bacteriuria & 124 & 110 & 14 & - & - \\
\hline $\begin{array}{l}\text { Doubtful } \\
\text { bacteriuria/Growth of } \\
\text { contaminants }\end{array}$ & 44 & - & - & 8 & 36 \\
\hline No growth & 32 & - & - & 2 & 30 \\
\hline Total & 200 & $\begin{array}{c}110 \\
(88.7 \%) \\
\text { Sensitivity }\end{array}$ & 14 & 10 & $\begin{array}{c}66 \\
(86.8 \%) \\
\text { Specificity }\end{array}$ \\
\hline
\end{tabular}

B)

\begin{tabular}{|c|c|c|c|c|}
\hline \multicolumn{5}{|c|}{ Urine culture } \\
\hline $\begin{array}{l}\text { Griess } \\
\text { Nitrite test }\end{array}$ & $\begin{array}{l}\text { Significant } \\
\text { bacteriuria } \\
(n=124)\end{array}$ & $\begin{array}{c}\text { Doubtful bacteriuria } \\
\text { Growth of } \\
\text { contaminants } \\
(n=44)\end{array}$ & $\begin{array}{c}\text { No } \\
\text { growth } \\
(n=32)\end{array}$ & Total \\
\hline Positive & $\begin{array}{c}110 \\
(88.7 \%)\end{array}$ & $\begin{array}{c}8 \\
(18.2 \%)\end{array}$ & $\begin{array}{c}2 \\
(6.2 \%)\end{array}$ & $\begin{array}{c}120 \\
(60 \%)\end{array}$ \\
\hline Negative & $\begin{array}{c}14 \\
(11.3 \%)\end{array}$ & $\begin{array}{c}36 \\
(81.8 \%)\end{array}$ & $\begin{array}{c}30 \\
(93.8 \%)\end{array}$ & $\begin{array}{c}80 \\
(40 \%)\end{array}$ \\
\hline Total & $\begin{array}{c}124 \\
(100 \%)\end{array}$ & $\begin{array}{c}44 \\
(100 \%)\end{array}$ & $\begin{array}{c}32 \\
(100 \%)\end{array}$ & $\begin{array}{c}200 \\
(100 \%)\end{array}$ \\
\hline
\end{tabular}

Table.7 Comparison of TTC test with culture method

A)

\begin{tabular}{|c|c|c|c|c|c|}
\hline Culture results & $\begin{array}{c}\text { Total no. of } \\
\text { samples }\end{array}$ & $\begin{array}{c}\text { True } \\
\text { positive }\end{array}$ & $\begin{array}{c}\text { False } \\
\text { negative }\end{array}$ & $\begin{array}{c}\text { False } \\
\text { positive }\end{array}$ & $\begin{array}{c}\text { True } \\
\text { negative }\end{array}$ \\
\hline Significant bacteriuria & 124 & 99 & 25 & - & - \\
\hline $\begin{array}{l}\text { Doubtful bacteriuria/ } \\
\text { Growth of } \\
\text { Contaminants }\end{array}$ & 44 & - & - & 10 & 34 \\
\hline No growth & 32 & - & - & 6 & 26 \\
\hline Total & 200 & $\begin{array}{c}99 \\
(79.8 \%) \\
\text { Sensitivity }\end{array}$ & 25 & 16 & $\begin{array}{c}60 \\
(78.9 \%) \\
\text { Specificity }\end{array}$ \\
\hline
\end{tabular}


B)

\begin{tabular}{|l|c|c|c|c|}
\hline $\begin{array}{l}\text { Urine culture } \\
\text { TTC } \\
\text { test }\end{array}$ & $\begin{array}{c}\text { Significant } \\
\text { bacteriuria } \\
(\mathbf{n = 1 2 4})\end{array}$ & $\begin{array}{c}\text { Doubtful } \\
\text { bacteriuria/ } \\
\text { Growth of } \\
\text { contaminants } \\
(\mathbf{n = 4 4 )}\end{array}$ & $\begin{array}{c}\text { No growth } \\
(\mathbf{n = 3 2})\end{array}$ & Total \\
\hline Positive & 99 & 10 & 6 & 115 \\
\hline Negative & 25 & $(22.7 \%)$ & $(18.8 \%)$ & $(57.5 \%)$ \\
\hline Total & $(20.2 \%)$ & $(74.3)$ & 26 & 85 \\
& $(124$ & 44 & $32 \%)$ & $(42.5 \%)$ \\
\hline
\end{tabular}

A)

\begin{tabular}{|l|c|c|c|c|c|}
\hline Culture results & $\begin{array}{c}\text { Total } \\
\text { no. of } \\
\text { samples }\end{array}$ & $\begin{array}{c}\text { True positive } \\
\text { ( out } \\
\text { of 124) }\end{array}$ & $\begin{array}{c}\text { False } \\
\text { negative } \\
\text { (out of 124) }\end{array}$ & $\begin{array}{c}\text { False } \\
\text { positive } \\
\text { (out of 76) }\end{array}$ & $\begin{array}{c}\text { True } \\
\text { negative } \\
\text { (out of 76) }\end{array}$ \\
\hline $\begin{array}{l}\text { Significant } \\
\text { bacteriuria }\end{array}$ & 124 & 100 & 24 & - & - \\
\hline $\begin{array}{l}\text { Doubtful } \\
\text { bacteriuria/Growth } \\
\text { of contaminants }\end{array}$ & 44 & - & - & 16 & 28 \\
\hline No growth & 32 & - & - & 6 & 26 \\
\hline Total & 200 & $\begin{array}{c}100 \\
(80.6 \%) \\
\text { Sensitivity }\end{array}$ & 24 & 22 & $\begin{array}{c}54 \\
(71.1 \%) \\
\text { Specificity }\end{array}$ \\
\hline
\end{tabular}

B)

\begin{tabular}{|c|c|c|c|c|}
\hline \multicolumn{5}{|c|}{ Urine culture } \\
\hline $\begin{array}{l}\text { Catalase } \\
\text { test }\end{array}$ & $\begin{array}{c}\text { Significant } \\
\text { bacteriuria } \\
(\mathbf{n}=124)\end{array}$ & $\begin{array}{c}\text { Doubtful } \\
\text { bacteriuria/ } \\
\text { Growth of } \\
\text { contaminants } \\
(n=44)\end{array}$ & $\begin{array}{c}\text { No growth } \\
(\mathbf{n}=32)\end{array}$ & Total \\
\hline Positive & $\begin{array}{c}100 \\
(80.6 \%)\end{array}$ & $\begin{array}{c}16 \\
(36.4 \%)\end{array}$ & $\begin{array}{c}6 \\
(18.8 \%)\end{array}$ & $\begin{array}{c}122 \\
(61 \%)\end{array}$ \\
\hline Negative & $\begin{array}{c}24 \\
(19.4 \%)\end{array}$ & $\begin{array}{c}28 \\
(63.6 \%)\end{array}$ & $\begin{array}{c}26 \\
(81.2 \%)\end{array}$ & $\begin{array}{c}78 \\
(39 \%)\end{array}$ \\
\hline Total & $\begin{array}{c}124 \\
(100 \%)\end{array}$ & $\begin{array}{c}44 \\
(100 \%)\end{array}$ & $\begin{array}{c}32 \\
(100 \%)\end{array}$ & $\begin{array}{c}200 \\
(100 \%)\end{array}$ \\
\hline
\end{tabular}


A)

Table.9 Results of leucocyte esterase dipstick test in comparison with culture method

\begin{tabular}{|c|c|c|c|c|c|}
\hline $\begin{array}{l}\text { Culture } \\
\text { results }\end{array}$ & $\begin{array}{c}\text { Total no. } \\
\text { of } \\
\text { samples }\end{array}$ & $\begin{array}{c}\text { True } \\
\text { positive }\end{array}$ & $\begin{array}{c}\text { False } \\
\text { negative }\end{array}$ & $\begin{array}{c}\text { False } \\
\text { positive }\end{array}$ & $\begin{array}{c}\text { True } \\
\text { negative }\end{array}$ \\
\hline $\begin{array}{l}\text { Significant } \\
\text { bacteriuria }\end{array}$ & 124 & 115 & 9 & - & - \\
\hline $\begin{array}{l}\text { Doubtful } \\
\text { bacteriuria/ } \\
\text { Growth of } \\
\text { contaminants }\end{array}$ & 44 & - & - & 4 & 40 \\
\hline No growth & 32 & - & - & 3 & 29 \\
\hline Total & 200 & $\begin{array}{c}115 \\
(92.7 \%) \\
\text { Sensitivity }\end{array}$ & 9 & 7 & $\begin{array}{c}69 \\
(90.8 \%) \\
\text { Specificity }\end{array}$ \\
\hline
\end{tabular}

B)

\begin{tabular}{|l|c|c|c|c|}
\hline $\begin{array}{l}\text { Leucocyte } \\
\text { esterase } \\
\text { dip-stick } \\
\text { test }\end{array}$ & $\begin{array}{l}\text { Significant } \\
\text { bacteriuria } \\
(\mathbf{n = 1 2 4})\end{array}$ & $\begin{array}{c}\text { Urine culture } \\
\text { Doubtful } \\
\text { bacteriuria/ } \\
\text { Growth of } \\
\text { contaminants } \\
(\mathbf{n = 4 4 )}\end{array}$ & $\begin{array}{c}\text { No growth } \\
(\mathbf{n = 3 2})\end{array}$ & Total \\
\hline Positive & 115 & 4 & 3 & 122 \\
\hline Negative & $(92.7 \%)$ & $(9.1 \%)$ & $(9.4 \%)$ & $(61 \%)$ \\
\hline Total & 9 & 40 & 29 & 78 \\
& $(7.3 \%)$ & $(90.9 \%)$ & $(90.6 \%)$ & $(39 \%)$ \\
\hline
\end{tabular}

Table.10 Comparison of different tests in terms of sensitivity, specificity and positive and negative predictive values

\begin{tabular}{|l|c|c|c|c|}
\hline TEST & $\begin{array}{c}\text { SENSITIVITY } \\
\text { \% }\end{array}$ & $\begin{array}{c}\text { SPECIFICITY } \\
\text { \% }\end{array}$ & $\begin{array}{c}\text { Positive predictive } \\
\text { value \% }\end{array}$ & $\begin{array}{c}\text { Negative predictive } \\
\text { value \% }\end{array}$ \\
\hline Wet mount (pus cells) & 87.1 & 82.9 & 89.3 & 80.8 \\
\hline Wet mount (bacteria) & 82.3 & 86.8 & 91.1 & 75 \\
\hline Gram staining & 85.5 & 89.5 & 92.9 & 79.1 \\
\hline Nitrite test & 88.7 & 86.8 & 91.7 & 82.5 \\
\hline TTC test & 79.8 & 78.9 & 86.1 & 70.6 \\
\hline Catalase test & 80.6 & 71.1 & 81.9 & 69.2 \\
\hline LE Dipstick test & 92.7 & 90.8 & 94.3 & 88.5 \\
\hline
\end{tabular}


Table.D1 Percentage of significant bacteriuria observed by different workers

\begin{tabular}{|c|l|c|c|}
\hline Sr. No. & Authors & Year & $\begin{array}{c}\text { \% of significant } \\
\text { bactetriuria }\end{array}$ \\
\hline 1 & Okonko $^{17}$ & 2010 & 47.5 \\
\hline 2 & Sharma $^{18}$ & 2012 & 65 \\
\hline 3 & Thakre $^{19}$ & 2012 & 9.6 \\
\hline 4 & Present study & 2015 & 62 \\
\hline
\end{tabular}

Table.D3 Sensitivity and specificity of le test observed in various studies
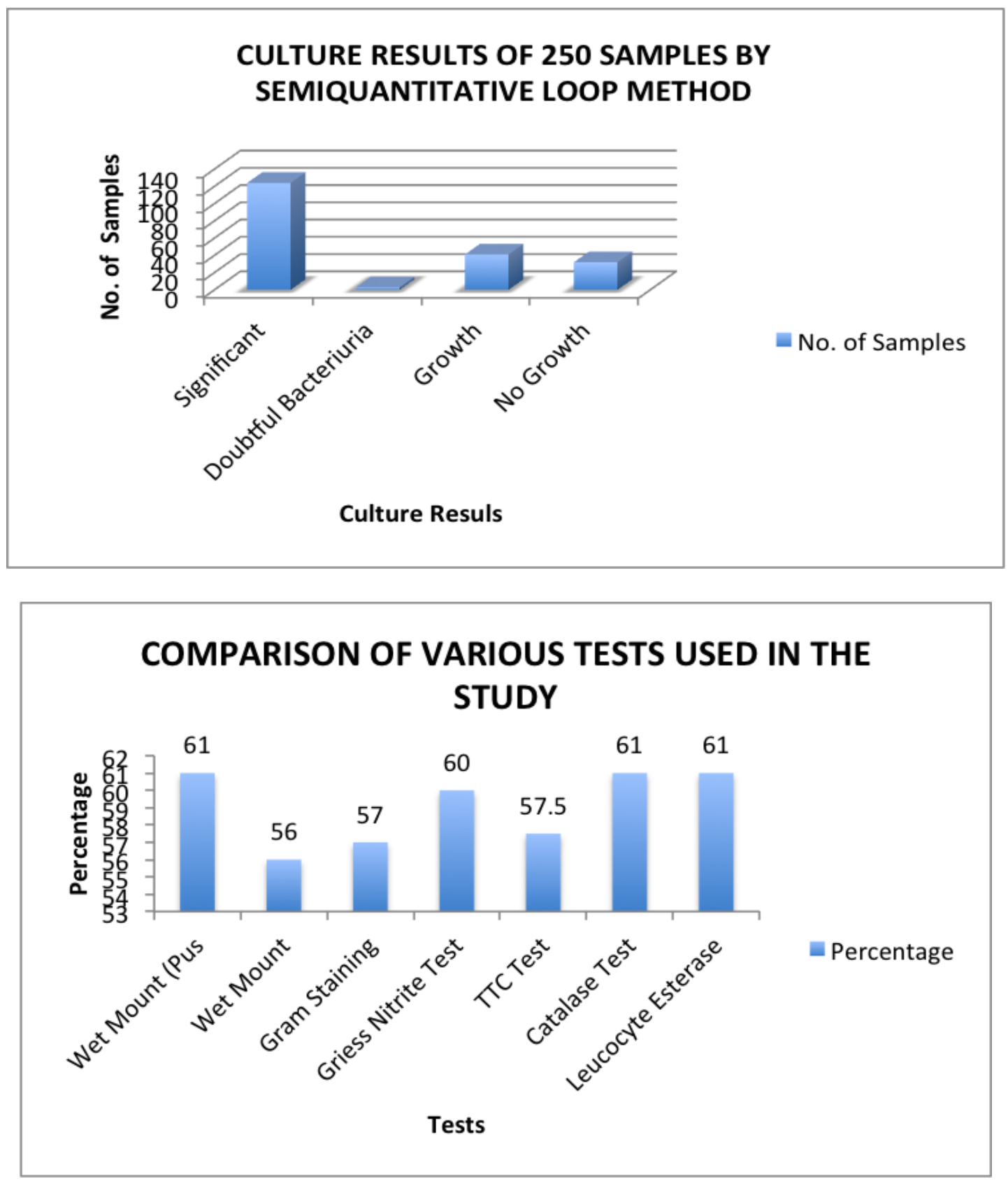
The present study evaluated 200 patient samples with clinical suspicion of the urinary tract infection, using cultural method and several rapid screening tests.

\section{Cultural analysis of study subjects}

Urine culture involves determination of the number of bacteria per unit volume, making it a semiquantitative analytical method. The count of viable bacteria in a mid-stream, clean catch urine sample serves as the gold standard for diagnosis of bacteriuria and hence diagnosis of UTI. In the present study, significant bacteriuria was observed in $62 \%$ cases, while doubtful bacteriuria for growth of contaminants was seen in $22 \%$ cases. Sterile cultures were encountered in $16 \%$ subjects. The percentage of significant bacteriuria reported in various studies is depicted in Table no. D1.

From the above Table D1 it is evident that rate of significant bacteriuria, thus indicating UTI, varied from $47.5 \%$ to $65 \%$. Finding similar to the present study was seen in the study of Sharma and Deepjyoti (2012), from Assam. ${ }^{18}$

The wide variation in the UTI prevalence among various studies is probably due to selection of different categories of patients, which extended from complicated and uncomplicated UTI, patients with obstruction, antenatal mothers and general population. A high UTI rate in the present study could be due to selection of patients, with careful history undertaken and exclusion of patients who had received antimicrobial therapy.

\section{Evaluation of screening tests}

Although cultural isolation remains the gold standard for arriving at a diagnosis of UTI, result of urine culture requires a minimum time of 24 to 48 hours to be ready. Rapid biochemical urine screening method, which would indicate a high suspicion of UTI could help in arriving at a presumptive diagnosis earlier. These tests could eliminate culturing of those samples which would yield no growth on culture. In the present study, various screening tests were evaluated in comparison with semi-quantitative urine culture, to determine the value of any screening method that would be sensitive without compromising on the specificity.

\section{Pyuria}

Wet mount examination for detection of pus cells on a centrifuged deposit was used. The sensitivity and specificity of this test $87.9 \%$ and $82.9 \%$ respectively. This test did not detect UTI in $12.1 \%$ culture confirmed cases, while false positivity was to the tune of $17.1 \%$. In a study by thakre and Supriya urine pus cells count could diagnose $72.41 \%$ culture positive UTI cases. ${ }^{19}$ Their false positivity was $5.53 \%$.

Pyuria may not be a specific finding. It may be present in cases without infection, as in cases with stones, following operations of urinary tract or in cases after treatment with antibiotics as stated by Brumfitt and Percival (1964).$^{20}$ Further, scientifically, sterile pyuria may be attributed to infections caused by fastidious organisms, such as chlamydia, which fail to grow on routinely employed urine culture media. A false negative result may be seen in UTI caused by organisms like Proteus, Klebsiella and Pseudomonas, which make the urine alkaline by virtue of the urease enzyme they possess. The alkaline urine could cause disintegration of pus cells.

\section{Bacteriuria}

Methodology employed and interpretative standards vary for detection of bacteriuria in unstained smears of whole or sediment urine. 
In the present study, unstained sediment from centrifuged urine was analysed for bacteriuria and the presence of at least 10 organisms/HPF was considered suggestive of infection.

The sensitivity of bacteriuria in the present study was $82.3 \%$ and specificity was $86.8 \%$, false positive result was seen in $13.2 \%$ cases, while false negative result was obtained in $17.7 \%$ subjects. Littlewood and Jacobs used the similar criteria as in the present study and observed a sensitivity of $87 \%$ and a specificity of $96 \% .{ }^{21}$ Although the sensitivity increased to $95 \%$, the specificity reduced to 50\%. Jenkins and Fenn (1986) opined that viewing more than 10 organisms/HPF should be the criteria to be employed as it correlates with 95\% specificity. This gives a high confidence of bacteriuria at a level of $10^{5}$ or more CFU/ml. ${ }^{11}$

\section{Gram staining}

The sensitivity of gram staining to predict UTI in the present study was $85.5 \%$ i.e. True positivity. This finding is in accordance with the result of studies conducted by Shaw and Karin (1988) who obtained a sensitivity $89 \%$ respectively. ${ }^{22}$

In the present study, the specificity was $89.5 \%$; similar to that obtained by Shaw and Karin (1998) i.e. $81 \% .^{22}$ False positive results with gram staining can be due to deposits in the gram stains. However, gram staining is a quick procedure and offers information of the type of organism, be it gram positive or gram negative, bacilli or cocci. It may also aide in separating low count bacteriuria from mixed morphology of normal urethral flora.

\section{Griess nitrite test}

The sensitivity and specificity of the Griess Nitrite test was $88.7 \%$ and $86.8 \%$ respectively. A false negative result was seen in $11.3 \%$ cases, while a false positive result was seen $13.2 \%$ cases. In a study conducted by Thakre and Supriya (2012) in Nagpur, the griess Nitrite test had a sensitivity of $79.31 \%$ and a specificity of $97.05 \% .{ }^{19}$ This test could not diagnose $20.67 \%$ UTI cases and among the negative urine cultures, it was positive in $2.95 \%$ cases.

A positive Griess Nitrite test indicates presence of nitrate reducing bacteria, especially the Enterobacteriaceae. Escherichia coli and Klebsiella, being predominant causative bacteria of UTI in the present study, contributed to a sensitivity of 88.7\%. A large number of Group D Streptococci $(20.9 \%)$ in the present study contributed to negative nitrite test as these organisms are nitrate negative. For a Griess nitrite test, the urine must have sufficient dietary nitrates which have remained in the bladder for at least 4 hours. Further, it is important to collect the first early morning sample for this test as stated by Thakre and Supriya (2012). ${ }^{19}$ A false negative result may be obtained if the patient has frequent bladder emptying and diuresis, infection with nitrate negative bacteria, lack of sufficient substrate and inhibition of metabolic activity of bacteria by antibiotics.

The practical significance of the Nitrite test is increased by the fact that Escherichia coli, a strong nitrate reducer is the most commonly encountered UTI associated pathogen. The striking simplicity of this test is an indication for this test to be employed routinely as tests for albumin and sugar as opined by Smith and Thayer (1961). ${ }^{23}$

\section{TTC test}

The TTC test is a salt reduction test, used for presumptive detection of evidence of UTI. In the present study, the sensitivity and specificity of TTC test was $79.8 \%$ and $78.9 \%$ 
respectively. This is in accordance with the finding of Agarwal and Das (1986) ${ }^{24}$ False positive result was obtained in $21.1 \%$ cases, in the present study. Simmons and William (1962) opine that contamination of urine with lactobacilli from the vagina may account for a positive test in bacteriologically significant cases. $^{25}$

Escherichia coli and Klebsiella which account for maximum number of urinary tract infection are TTC test positive and therefore help to improve the usefulness of the test. Since bacteria reduce colourless TTC to an insoluble red compound at an alkaline $\mathrm{pH}$ a false result may be obtained at a low $\mathrm{pH}$ equal to or less than 6.5 .

\section{Catalase test}

This test showed a sensitivity of $80.6 \%$ and a specificity of $71.1 \%$ in the present study. Similar sensitivity of $83 \%$ and specificity of $70.9 \%$ was observed in a study conducted by Berger and Bianca on 500 urine samples from cases of suspected UTI. ${ }^{26}$ A false negative result was seen in $19.4 \%$ cases in the present study. Similar, $17 \%$ cases yielded false negative result in the study of Berger and Bianca. $^{26}$

False negative result can be due to simple bacilluria which do not produce renal injury and thereby fail to produce renal catalase. Braude and Berkowitz (1961) opined that net urinary catalase represents the sum of renal, exudative and microbial catalase traces from any one of the three sources alone might not be detected. ${ }^{27}$ False negative result can also be due to some urinary pathogens that lack catalase, such as Enterococci. Drugs like thallium, a catalase inhibitor can also contribute to a negative catalase result as stated by Braude and Berkowitz (1961). ${ }^{27}$

A false positive result was seen in $28.9 \%$ cases, in the present study. A false positive result can be obtained because catalase is also produced by inflammatory cells and renal tissue. Presence of red blood cells can also give a false positive result as seen by Taguchi and $\mathrm{Grad}^{28}$

\section{Leucocyte esterase dipstick test}

The Leucocyte Esterase test is a rapid screening test for LE activity (host response specific) and a test for urinary nitrite production which is bacteria specific. Table no. D3 compares the sensitivity and specificity of the LE dipstick test in various studies and as well as in the present study.

From the above Table D3, the sensitivity of LE test in the present study was $92.7 \%$ and comparable with $97.1 \%$ obtained by Waisman and Zerem (1999). ${ }^{29}$ A low sensitivity of 50\% was observed in the study of Teresa (1985) and Eigbefoh. ${ }^{30}$ The specificity of the test was $90.8 \%$ in the present study and was comparable with result obtained in the studies of Teresa et al., (1985) ${ }^{30}$ Shaw and Karin $(1998)^{22}$ It has been observed that presence of ascorbic acid, phenazopyridine or abnormal concentration of protein may interfere with the LE test and give erratic results as observed by Wagle and Vaidya. ${ }^{31}$

\section{Comparison of different tests used in the study}

In the recent years, a number of tests have been introduced to detect bacteria and leucocytes in urine. Urine culture, which remains the gold standard for UTI diagnosis, takes 24 to 48 hours to yield a confirmatory report. Clinicians require speedy results which are accurate. Therefore, a number of rapid urine screening methods have been tried. Berger and Bianca (1990) are of the opinion that these rapid urine screening methods have often traded specificity for sensitivity and simplicity. ${ }^{26}$ 
In the present study, LE test showed the highest sensitivity (92.7\%) followed by nitrite test $(88.7 \%)$, wet mount for pus cells $(87.1 \%)$, gram staining $(85.5 \%)$ and wet mount for bacteria $(82.3 \%)$. The TTC test had the lowest sensitivity (79.8\%). Thus the LE cell appeared to be relatively more useful in detecting UTI cases. However, taking into consideration, the cost factor of the LE test, in a setting like ours, one would resort to nitrite test, wet mount for pus cells or gram staining.

Although the nitrite test appeared to be marginally better, in terms of sensitivity, when compared with pus cells wet mount and gram staining, it is impertinent to obtain first morning sample of urine for the nitrite test. This will allow sufficient time for the enzyme production and obviate false negative result as stated by Smith and Thayer. ${ }^{23}$ Gram staining, on the other hand, allows presumptive identification of the type of organism responsible for UTI, based on the morphology and staining properties. This information can be made available to the clinician to choose the appropriate antibiotic before obtaining the culture result.

The specificities of LE dip stick test, Griess Nitrite test, gram staining, wet mount for bacteria and wet mount for pus cells were comparable i.e. $90.8 \%, 86.8 \%, 89.5 \%, 86.8 \%$ and $85.5 \%$ respectively. This indicates that the tests picked up true positives in relatively similar frequency. The result from the present study indicates that the LE dipstick test is the most sensitive and specific test for screening cases of bacteriuria and UTI. Although, the test is rapid and simple, it is not cost effective and cannot be undertaken as a routine.

In conclusion, the present study evaluated bacteriological culture analysis of 200 urine samples from clinically suspected cases of urinary tract infections, along with rapid screening tests for diagnosis.
1. Culture analysis by semi-quantitative loop method was as follows:-

a) Significant bacteriuria was seen in $62 \%$ cases $(124 / 200)$.

2. Result of Rapid screening tests revealed the following:-

a) Wet Mount urine examination for pyuria suggested UTI in $61 \%$ cases

b) Wet Mount examination for bacteria was suggestive in $56 \%$ cases.

c) Gram staining suggested UTI in 57\% cases.

d) Griess Nitrite positive test was obtained in $60 \%$ cases.

e) TTC test suggested evidence in $57.5 \%$ cases.

f) Catalase test was positive in $61.0 \%$ cases.

g) Leucocyte Esterase dip stick test showed a positive result in $61 \%$ cases.

3. Comparison of all rapid tests with culture result showed the followed:-

a) Sensitivity of LE test was test was highest $(92.7 \%)$ followed by Griess Nitrite test $(88.7 \%)$ and wet mount for pyuria $(87.1 \%)$.

b) Negative predictive value was highest with Leucocyte Esterase test (88.5\%).

c) The specificity was highest with LE dipstick test $(90.8 \%)$.

\section{References}

1. D. Prakash and R. S. Saxena, "Distribution and antimicrobial susceptibility pattern of bacterial pathogens causing urinary tract infection in Urban Community of Meerut City, India," ISRN Microbiology, vol. 2013, Article ID 749629, 13 pages, 2013.

2. Warren JW, Abrutyn E, Hebel JR, Johnson JR, Schaeffer AJ, Stamm WE, et al., Guidelines for antimicrobial treatment of uncomplicated acute bacterial cystitis and acute pyelonephritis in women. 
Infectious Diseases Society of America (IDSA). Clin Infect Dis 1999; 29: 74558.

3. J. Sabrina, "Antimicrobial resistance among producers and non-producers of extended spectrum beta-lactamases in urinary isolates at a tertiary Hospital in Tanzania," BMC Research Notes, vol. 3, p. 348, 2010.

4. V. Lacovelli, G. Gaziev, L. Topazio, P. Bove, G. Vespasiani, and A. E. Finazzi, "Nosocomial urinary tract infections: a review," Urologia, vol. 81, no. 4, pp. 222-227, 2014

5. Flores-Mireles, A.L., Walker, J.N., Caparon, M., and Hultgren, S.J. Urinary tract infections: epidemiology, mechanisms of infection and treatment options. Nat Rev Microbiol. 2015; 13: 269-284

6. Glaser, A.P. and Schaeffer, A.J. Urinary tract infection and bacteriuria in pregnancy. Urol Clin North Am. 2015; 42: 547-560

7. Pezzlo M. Detection of urinary tract infections by rapid methods. Clinical Microbiology Reviews. 1988; 1: 268280.

8. Colombrita D, Ravizzola G, Pirali F, Manni M, Manca N, Savoldi E et al., Journal of Clinical Microbiology. 1989; 27(1): 118-119.

9. Hoeprich PD. Culture of urine. Journal of laboratory clinical medicine. 1960; 56: 899-907.

10. Stokes EJ, Ridgway GL, Wren MWD. Clinical Microbiology, 1983, Seventh Edition, Edward Arnold Pub, London. 1983; p. $45-47$.

11. Jenkins RD, Fenn JP, Matsen JM: Review of urine microscopy for bacteriuria. The Journal of the American Medical Association. 1986; 255(24): 3397 3403.

12. Schaus R. Griess' Nitrite Test in Diagnosis of Urinary Infection. JAMA.
1956; 161(6): 528-529.

13. Simmons NA, Williams JD. A simple test for significant bacteriuria. The Lancet. 1962; 1377-1378.

14. Lie JT. Screening tests for significant bacteriuria: A comparison of the catalase test with microscopy of the unstained sediment. The Journal of Urology. 1968; 100: 772-774.

15. Bartlett RC, O’Neill D, Mc Laughlin JC. Detection of bacteriuria by leucocyte esterase, nitrite and automicrobic system. The American journal of clinical pathology. 1984;82(6):683-687.

16. Smith TM, Hudson AJ, Spencer RC. Evaluation of six screening methods for detecting significant bacteriuria. Journal of Clinical Pathology. 1988; 41: 904909.

17. Okonko I. O., Ijandipe L. A., Ilusanya et al., detection of urinary tract infection among pregnant women in Oluyoro catholic hospital, Ibadan, south-western Nigeria. Mslsysian $\mathrm{J}$ of Microbiol. 2010;6(1):16-24.

18. Indu Sharma, Deepjyoti Paul. Prevalence of community acquired urinary tract infections in silchar medical college, Assam, India and its antimicrobial susceptibility profile. 2012; 66(11): 273-279.

19. Sushma Thakre, Supriya Dhakne, Subhash Thakre. Can the Griess nitrite test and a urinary pus cell count of $\geq 5$ cells per microlitre of urine in pregnant women be used for the screening or the early detection of urinary infections in Rural India. J Clin Diag Res. 2012; 6(9): 1518-1522.

20. Brumfitt W, Percival A; Pathogenesis and laboratory diagnosis of non tuberculous urinary tract infection. A review. $\mathrm{J}$ of clinical Pathol. 1964; 17: 482-491

21. Littlewood JM, Jacobs SI, Ramsden CH. Comparison Between Microscopical 
examination of unstained deposits of urine and quantitative culture. Arch Dis Child. 1977; 52: 894-896.

22. Kathy N Shaw, Karin L., Mc Gowan. Screening for Urinary tract Infection in infants in the Emergency Department: Which Test is best? 1998; 101(6).

23. Smith LG, Thayer WR, Malta EM, Utz JP. Relationship of the Griess nitrite test to bacterial culture in the diagnosis of urinary infection. Annals of Internal Medicine. 1961; 54: 66- 72.

24. Agrawal SK, Das R, Goel MM, Kumar M. Tetrazolium Reduction test in diagnosis of urinary tract infections. Indian J. Pathol. Microbiol. 1986; 29: 61-65.

25. Simmons NA, Williams JD. A simple test for significant bacteriuria. The Lancet. 1962; 1377-1378.

26. S. A. Berger, Bianca B, Colin B. Rapid Screening of urine for bacteria and cells by using a catalase reagent. $\mathrm{J}$ of Clinical Microbiology. 1990; 28(5): p. 10661067.
27. Braude AL, Berkowitz H. Detection of urinary catalase by disc floatation. $\mathrm{J}$ of Laboratory and clinical medicine. 1961;57(3):490-494.

28. Taguchi Y, Grad B. Simple screening test for significant bacteriuria in urine. Catalase Determination by disk flotation method. Urology. 1976;8(3):240 - 242.

29. Waisman Y, Zerem E, Amir L, Mimouni M. The validity of the uriscreen test for early detection of urinary tract infection in children. Padiatrics. 1999; 104(4):41.

30. Teresa CWU, Williams EC, Koo SY, Mac Lowry JD. Evaluation of three bacteriuria screening methods in a Clinical Research Hospital. Journal of Clinical Microbiology. 1985; 21(5): 796-799.

31. Wagle N, Vaidya A, Joshi S, Merchant SM. Triphenyl tetrazolium chloride (TTC) dye test for quick diagnosis of urinary tract infection. Indian $\mathrm{J}$ Padiatr. 1989; 56(5): 635-8.

\section{How to cite this article:}

Pradnya Naik and Maria Jose Pinto. 2019. A Study of Screening Tests for the Presumptive Diagnosis of Significant Bacteriuria in Urinary Tract Infections. Int.J.Curr.Microbiol.App.Sci. 8(09): 667-683. doi: https://doi.org/10.20546/ijcmas.2019.809.080 